\author{
St ud i a P ilosophic a \\ Wrat i s l a vi e n s i a \\ vol. XV, fasc. 2(2020) \\ https://doi.org/10.19195/1895-8001.15.2.11
}

DOMINIKA JACYK

ORCID: 0000-0002-5423-1088

Uniwersytet Wrocławski

\title{
Kryzys, krytyka, mądrość. Kantowskie ujęcie mądrości i jego aktualność
}

\section{Crisis, Criticism, Wisdom: Kant on Wisdom and Its Actuality}

\begin{abstract}
The title concepts of criticism, crisis, and wisdom are taken from the paradigm of Kantian philosophy and are characterised in the development given by the contemporary philosopher Odo Marquard. In this connection I present the relationship between wisdom and thinking in the Enlightenment usage. The call for philosophy to be self-understanding in the sense of the Enlightenment Bildung and the autonomy of science and wisdom sounds particularly strong here. I conclude that philosophy becomes stupidity when it turns into a field that - because of some kind of philosophical fundamentalism - would like to become this one-sided attitude towards reality that eliminates and replaces other attitudes.
\end{abstract}

Keywords: crisis, criticism, wisdom, Kant, Marquard

Tytułowe terminy odwołuja się do trzech elementów, które — historycznie - współtworzą dziedzinę kantowskiej filozofii transcendentalnej inicjującej myślenie krytyczne. Krytycyzm reprezentuje kantowskie rozumienie racjonalności, która jest synonimem mądrości. Kantowskie rygory stawiane każdemu myśleniu krytycznemu wpisują się jak najbardziej w etymologiczne credo samej filozofii. Dla królewieckiego filozofa racjonalne postępowanie jest bowiem tożsame z nauką mądrości, jak ujmował to dawniej Arystoteles w swym Protreptyku ${ }^{1}$, a ta z kolei, jako nauka, jest wskazaniem tego, co należy do najwyższego dobra, przez które

${ }^{1}$ Por. Arystoteles, Zachęta do filozofii, tłum. K. Leśniak, [w:] idem, Dzieła wszystkie, t. 6, Warszawa 2001 , s. 637. 
można pozyskać mądrość, czyli granice podmiotowego poznania. Dla Kanta nauka ma bowiem prawdziwą wartość tylko w granicach wyznaczonych przez antynomie czystego rozumu teoretycznego, sam zaś filozof, który jest przewodnikiem owego rozumu, prowadzi człowieka w obszarze wytyczonym przez krytyczne myślenie ku mądrości. Jako filozof jest nauczycielem mądrości, a jako kreator rozumu jest nauczycielem wiedzy. Omawiane poniżej ostatnie myśli Kanta krążą w jego Opus posthumum wokół mądrości wyobrażonej jako uosobienie celu rozumu doskonałego, przedstawionych już nie jako agregat, ale jako całość systemu. W tych analizach chciałabym, z jednej strony, scharakteryzować wątki Kanta dotyczące mądrości jako myślenia krytycznego, z drugiej zaś pokazać ich aktualność we współczesnych dyskusjach filozoficznych.

Tytułowe terminy wskazują na trzy uniwersalne elementy, które chcę potraktować jako, z jednej strony, klisze interpretacyjne skutkujące pewnym przełomem, jakim był niewątpliwie przewrót kopernikański Kanta, z drugiej zaś pojęcie mądrości chcę uznać za swoistą klamrę, domykającą schemat kantowskiej konstrukcji filozoficznej. W dzisiejszej kulturze, którą zaczyna się określać jako postpiśmienną, kantowskie rozwinięcie rozumienia kryzysu, krytyki i mądrości, szczególnie w rozumieniu, jakie nadał im współczesny filozof Odo Marquard ${ }^{2}$, są bez wątpienia uniwersalnie ważne, dlatego jego charakterystykę potraktuję jako bazową dla moich rozważań.

We współczesnym dyskursie, nie tylko humanistycznym, ważność pojęcia mądrości zastąpiło pojęcie wiedzy. Gabriel Marcel pisał:

pewne słowa, a nawet pojęcia, do niedawna jeszcze posiadające niekwestionowane znaczenie i szanowane, niczym rodzinne portrety w opuszczonym zamku pokrywają się warstwą kurzu, która gasi ich blask. Ośmielę się powiedzieć, że tak właśnie dzieje się ze słowami mądrość i sacrum³

W rozprawie, jeszcze z tak zwanego okresu przedkrytycznego, zatytułowanej Co zwie się Oświeceniem, postulując odwagę myślenia, Kant wiąże je z mądrością, albowiem tylko myślącemu myśl „daje coś do myślenia”. Dlatego ten, kto chce być/uchodzić za mądrego, winien zdaniem Kanta przede wszystkim samodzielnie myśleć, a w obcowaniu z ludźmi wmyślać się w sytuację drugiego i w procesie mentalnego autoargumentowania być w zgodzie z sobą samym ${ }^{4}$.

Na czym polegają wskazane komponenty — „myśleć samodzielne” i „wmyślać się w sytuację innego"? Zakładają one, że podmiot kieruje się w tym namyśle głównie dobrem, rozumianym nie tylko jako skoncentrowanie się na własnych korzyściach, lecz także, a może przede wszystkim, jako rozumienie cudzego dobra, dobra drugiego człowieka i jego, czyli cudzego, interesu. Kantowskie myślenie płynie tutaj w nurcie filozoficznej refleksji nad dobrem, którą jako jeden z pierwszych podjął Arystoteles, wiążący mądrość z dobrym namysłem, który w Etyce Nikoma-

${ }^{2}$ O. Marquard, Drei Betrachtungen zum Thema Philosophie und Weisheit, [w:] idem, Individuum und Gewaltenteilung, Stuttgart 2004, s. 97-113 [przekład polski: Trzy rozważania o filozofii i mądrości, tłum. P. Głowacki, J. Nowak, R. Specht, „Studia z Historii Filozofii” 2 [7] (2016), s. 45-57].

${ }^{3}$ Cyt. za: T. Gadacz, Uniwersalne prawdy i prawa życia dla madrych ludzi na trudne czasy, Kraków 2018 , s. 92.

${ }^{4}$ I. Kant, Co to jest Oświecenie, [w:] Z. Kuderowicz, Kant, Warszawa 2000, s. 194. 
chejskiej pisał: „Dobrze zaś w bezwzględnym tego słowa znaczeniu namyśla się ten, kto zgodnie z wynikami swojego rozumowania umie zmierzać do największego dla człowieka dobra"5. Filozof z Królewca, tak jak większość myślicieli, podkreśla tu wyraźny, wręcz fundamentalny, związek między mądrością i dobrem.

Z kolei związek między mądrością a myśleniem zakłada umiejętność rozpoznawania, czyli mądrość praktyczną, określoną zwięźle jako rozsądek, będącą tłumaczeniem używanego przez Arystotelesa greckiego terminu phronesis. Tak pojmowana mądrość odpowiada na pytanie, jak winniśmy postępować.

Brak władzy rozpoznawania jest właściwie tym, co nazywamy głupotą, a tej ułomności nie można zaradzić. Głowę tępą lub ograniczoną, której brak należytego stopnia rozsądku i własnych jego pojęć, można bardzo dobrze wyposażyć nauczoną wiedzą, nawet uczonością. Ponieważ jednak wtedy zazwyczaj brak owej szczypty mądrości ( secunda Petri), to nie jest niczym niezwykłym, że spotyka się bardzo uczonych ludzi, którzy w stosowaniu swej nauki często zdradzają ów brak niczym niedający się naprawić ${ }^{6}$.

Pokazuje to, iż mądrość nie jest jedynie zwykłym zebraniem czy skatalogowaniem posiadanych wiadomości, a czymś wyższym, czymś więcej, pewnym naddatkiem, o którym przy okazji pojęcia świętości pisał Rudolf Otto?

Warto zatem zapytać: o czym więc rozstrzyga rozsądek jako władza nazywana przez Kanta umiejętnością rozpoznawania? Czyż właściwie nie powinien rozsądzać o tym, co najistotniejsze w nieusuwalnej złożoności każdego ludzkiego doświadczenia? Złożoność ta bowiem uruchamia wiele pól, dziedzin czy przestrzeni, na których owo doświadczenie się odbywa i domaga się własnej artykulacji. Wobec tego, że człowiek niejako uruchamia się całym sobą, czyli złożeniem współistniejacych w nim sprzeczności i dopełnień, to jako istota materialna i duchowa (materialno-duchowa) jest zanurzony w rzeczywistości przyrodniczej i kulturowej zarazem, jako jednostkowy podmiot tworzy swoją odrębność i jest tym samym indywidualny, ale jest jednocześnie wspólnototwórczy, wolny i odpowiedzialny, aktywny i pasywny. Dlatego potrzeba mu miary jako znamienia rozsądku i mądrości, wolność bowiem bez odpowiedzialności za swe czyny skutkuje rozkładem i anarchią, samowładna zaś odpowiedzialność bez wolności rodzi tyranię. Hiperindywidualizm wyzuty z jakichkolwiek relacji społecznych ewoluuje we współczesny egoizm, będący bardzo często spłyceniem idei samorealizacji jednostki. Jak pisze Tadeusz Gadacz:

Kontemplacja pozbawiona działania może się przemienić w narcyzm, a działanie bez kontemplacji w czysty aktywizm. Gdzie ma przebiegać granica między życiem zaangażowanym w materialność a otwarciem się na duchowość, gdzie ograniczyć miłość na rzecz sprawiedliwości lub sprawiedliwość na rzecz miłości, wolność na rzecz odpowiedzialności lub odpowiedzialność na rzecz wolności, relacje społeczne na rzecz samotności lub samotność na rzecz relacji? Na to pytanie może każdorazowo odpowiedzieć nam jedynie mądrość. Mądry jest ten, kto umie tę granicę każdorazowo określić. A określić ją nie jest łatwo, gdyż za każdym razem leży ona gdzie indziej ${ }^{8}$.

${ }^{5}$ Arystoteles, Etyka Nikomachejska, 1141b, tłum. D. Gromska, Warszawa 1956, s. 218.

${ }^{6}$ I. Kant, Krytyka czystego rozumu, tłum. R. Ingarden, t. 1, Warszawa 1986, s. 283.

${ }^{7}$ Por. R. Otto, Świętość. Elementy irracjonalne $w$ pojęciu bóstwa $i$ ich stosunek do elementów racjonalnych, tłum. B. Kupis, Warszawa 1999, s. 9.

${ }^{8}$ T. Gadacz, Uniwersalne..., s. 96. 
Reguły mądrego działania są jednak czymś zupełnie innym niż mądrość jako taka; mądrość jedynie praktyczna jest czymś zupełnie innym niż opisywana często przez filozofów mądrość teoretyczna.

Na stosunek do mądrości, jaki prezentował królewiecki filozof, można spojrzeć jednak jeszcze z innej niż tylko rudymentarnej perspektywy, narzucającej się nam zazwyczaj jako pierwsza. Kant nie zajmował się mądrością in statu nascendi, ale wielokrotnie wykorzystywał to pojęcie operacyjnie. Według Marquarda u Kanta obserwujemy, jak ,filozofia mająca skłonność do nauki pozornie pozostawia w tyle umiłowanie mądrości"9. Krytyczność czystego rozumu spekulatywnego nie wiedzie bowiem u Kanta do mądrości, ale do granic wiedzy, a w konsekwencji do nauki. Widać to wyraźnie między innymi we fragmencie z Krytyki praktycznego rozumu:

Dopiero ograniczenie czystego rozumu pod względem spekulatywnym, a jego rozszerzenie pod względem praktycznym doprowadzają go do tego stosunku równości, w jakim w ogóle daje się z rozumu uczynić celowy użytek; i przykład ten dowodzi lepiej niż każdy inny, że droga do mądrości, jeżeli ma być bezpieczna, a nie drogą nie do przebrnięcia lub wiodąca na manowce, musi u nas ludzi prowadzić nieuchronnie przez naukę; o tym jednak, że nauka wiedzie do owego celu, można się przekonać dopiero po jej doprowadzeniu do końca ${ }^{10}$.

Ścieżka filozofii skręca tym samym ze swym przedmiotem z umiłowania mądrości ku tym szlakom, które prowadzą na tory teorii nauki. Dokonuje się to nie przez zmianę paradygmatu definicji czy pojmowania filozofii, lecz przez zmianę paradygmatu nauki, jaka następuje w okresie nowożytności również w filozofii. W nowożytności bowiem, jak pisze Marquard, poszukiwanie mądrości pozostawia się nienaukowym fascynatom lub wielbicielom filozofii popularnej. Zagadnienie mądrości zostaje niejako wypchnięte z obszaru nauki, uznane nie tyle za bezprzedmiotowe lub niefilozoficzne, ile za teoretycznie nieatrakcyjne, a jako pierwszy promotor tej zmiany wymieniony zostaje Kartezjusz, zaraz za nim pojawia się jednak nazwisko Kanta. Jest to sytuacja w filozofii dość osobliwa, albowiem nie tylko w starożytności, ale jeszcze w średniowieczu filozofia legitymizowała samą siebie jako umiłowanie mądrości, co więcej — ujmowano ją jako „receptę” na mądrość, czyli umiejętność odróżniania tego, co błahe, od tego, co ważne, co pozwalało z kolei na poczucie, iż spędza się życie godnie, a unika życia niegodziwego.

Wiązanie filozofii z mądrością, nie tylko z powodu źródeł czysto etymologicznych, jest z rzeczywistych względów słuszne, ale u Kanta ta etymologia wchodzi w ciekawe korelacje prowadzące do wyłaniania się świadomości kryzysu i potrzeby krytyki w obszarze filozofii. Czy filozofia Kanta, reprezentująca przecież osiemnastowieczne ideały, jest dzisiaj nadal ideowo (filozoficznie) atrakcyjna? Dzisiejsza nauka raczej zdecydowanie dystansuje się wobec oświeceniowej nadziei na stały postęp ludzkości, racjonalny optymizm i przekonanie, że nad wszystkim, co spotyka człowieka, będzie on zdolny zapanować. Mimo że te stanowiska uznaje się już za przebrzmiałe, nie tylko z powodów czysto historycznych, to jednak oświeceniowe rozumienie rozumu i jego granic, krytyki i wewnętrznej dojrzałości, wolności i jej

\footnotetext{
${ }^{9}$ O. Marquard, Trzy rozważania..., s. 45.

${ }^{10}$ I. Kant, Krytyka praktycznego rozumu, tłum. J. Gałecki, Warszawa 1984, s. 226-227.
} 
wymogów stanowi nie tylko uniwersalnie ważne zadania dla każdego współczesnego człowieka, ale reprezentuje korpus współcześnie istotnych postaw mądrościowych i dlatego niewattpliwie wykracza poza XVII i XVIII stulecie.

Co ciekawe, sam Kant jest niewątpliwym prekursorem wielu oświeceniowych idei filozoficznych i najdobitniej je wyraża, lecz zarazem tryptyk jego trzech krytyk stanowi zalążek ich przyszłej transformacji i źródło mądrości przyszłych pokoleń intelektualistów.

Znana dewiza sapere aude, przedstawiona w wersji Kanta, jest próbą zrozumienia tego, co znaczy mieć odwagę posługiwać się własnym rozumem. Według Kanta jest to proces rozwijania intelektualnej, wewnętrznej autonomii — zainicjowany jest przez decyzję o zdaniu się na własne myślenie. Nie tylko — jak powiedzielibyśmy w dzisiejszym języku - bycie wewnątrzsterownym, lecz właśnie tropienie własnych błędów i usuwanie przesądów czy stereotypów. Co więcej, sapere aude wzywa do porzucenia własnych partykularnych interesów, by krok po kroku postępować w dojrzałym ukształtowaniu ,powszechnego rozumu ludzkiego”. Tak brzmi wezwanie do mądrości ówczesnego, ale i — mam nadzieję — współczesnego podmiotu myślącego.

Myślenie Immanuela Kanta nie zadowala się zwykle wymiarem tych wyzwań, ale na polu filozofii teoretycznej i praktycznej daleko je pogłębia i poszerza. Przede wszystkim krytykuje różne, ówcześnie modne, filozofie dogmatyczne i odkrywa ostateczne podstawy rozumu (tym właśnie jest krytyka rozumu). Postawa ta reprezentuje między innymi autonomię rozumu i wolność rozumianą jako źródło zasadniczych praw samosprawczego rozumu. Wychodząc od wewnętrznych problemów zastanej filozofii, Kant nie tylko skutecznie dociera do źródeł tych problemów, lecz także wyznacza granice rozumu, poza które nie jest on w stanie już sięgać. Zdradza tym postawę mędrca adekwatnie rozpoznającego swoisty skandal, z którym filozofia powinna się uporać: spór wokół własnych zasad.

Ówczesne nauki były pod silnym wrażeniem progresu i sukcesu nauk przyrodniczych, zwłaszcza fizyki, indukowanego rozwojem logiki i matematyki. Sukces nauk o naturze stanowi nie tylko wyzwanie, lecz także negatywne tło dla filozofii miotanej sporami wokół kwestii Boga, wolności i nieśmiertelności duszy (głównych — jak sądził między innymi Christian Wolff — problemów metafizyki), których nie tylko przebieg, ale i wynik trudno naukowo prognozować. By wprowadzić metafizykę na tory badania naukowego, by ująć metafizykę jako naukę, królewiecki mędrzec podejmuje prymarne kwestie metafizyczne: Boga, duszy i świata z nowego poziomu, niepodejmowanych z tej perspektywy, zasadniczych pytań. Odwaga pytania: „jak jest możliwa metafizyka, która mogłaby wystąpić jako nauka?" rozpościera przed filozofią nowy styl formułowania ważnych zagadnień.

Dlatego filozofia w ujęciu Immanuela Kanta przyjmuje zlecenie zanalizowania swych własnych możliwości, co prowadzi do — nieznanego dotąd w niej — radykalizmu. Emblematycznym znakiem tego radykalizmu jest nowy sposób myślenia, który Kant odkrywa w Krytyce czystego rozumu. Filozof tropiąc wyznaczniki autonomii rozumu, pisze, iż nie da się jej wyznaczyć arbitralnie lub sformułować tylko abstrakcyjnie, lecz jedynie w toku szczegółowego badania centralnych problemów merytorycznych. W analizie o wzorcowej oryginalności dochodzi do wniosku, 
że filozofia jako nauka rozumowa zakłada bowiem — co właśnie jest odkryciem Kanta - że w ludzkim poznaniu i działaniu, w religii, historii, prawie, sądach estetycznych występują sądy, których wartość jest całkowicie niezależna od wszelkiej empirii, nie rozpoznaje się ich w poznaniu doświadczalnym, lecz metateoretycznie rozważa przez samą analizę.

Na czym polegał kryzys, który zdiagnozował Immanuel Kant? Na czym polega krytyka, którą zaproponował? Jaka mądrość może wynikać dla współczesnych z nieprzerwanego oddziaływania jego pism filozoficznych? Zdaniem Höffego, mimo iż Kant jest jednym z najwybitniejszych klasyków filozofii, to nie możemy go czcić jako prekursora teraźniejszości. Zwraca on uwagę, iż w wielu obszarach krytyka jego stanowiska jest dyskredytująca lub — co najmniej — zastanawiajacca.

Pozytywizm logiczny i filozofia analityczna kwestionują elementy ściśle niezależne od doświadczenia i tak samo jak strukturalizm postulują rezygnację z wszelkiego ostatecznego uzasadnienia. W etyce wyzwaniem wobec Kanta będzie utylitaryzm, a następnie etyka dyskursu, jeśli chodzi o filozofię wolności — determinizm i behawioryzm, jeśli chodzi o filozofię prawa — pozytywizm. Jednym słowem Kant pozostaje w sprzeczności z ważnymi tendencjami w filozofii, nauce i polityce ${ }^{11}$.

Uniwersalnie ważne, płodne dla konstytuowania się mądrości wydają się wobec tego przede wszystkim przewodnie kantowskie pytania wynikające z napięcia pomiędzy diagnozowanym kryzysem a projektowaną krytyką, co jest też przykładem stałej tendencji królewieckiego filozofa jako myśliciela. Stara się on odważnie podejmować dyskusje z aktualnym polem doświadczenia filozoficznego, właściwie je diagnozować i twórczo komentować, otwierając całkowicie nowe perspektywy badawcze. W tym jest on dla nas prekursorem i może być źródłem mądrości wartym naśladowania.

Diagnozowany i charakteryzowany przez Kanta kryzys skutkuje zagmatwaną czy nieczytelną sytuacją metafizyki, która wydaje się — z jednej strony — jak najbardziej konieczna i niezbędna, a zarazem — z drugiej — niemożliwa. Próba uzyskania poznania niezależnego od doświadczenia, a więc poznania a priori, spycha rozum w mrok, wewnętrzne sprzeczności i przeciwstawne stwierdzenia, i w konsekwencji prowadzi do niekończących się filozoficznych sporów. Kant posądza filozoficznych racjonalistów, takich jak Kartezjusz, Spinoza, Malebranche i Leibniz, o dogmatyzm i despotyzm, ponieważ bez przeprowadzenia jakiejkolwiek krytyki rozumu chcą oni narzucać podmiotowi określone prawa podstawowe, dotyczące na przykład niezłożonej natury duszy, jej nieśmiertelności, istnienia Boga czy początku świata. Z kolei sceptyków filozoficznych posądza o podkopywanie wszelkiego ludzkiego poznania. Próby sformułowania jakiegoś remediu m na kondycję ówczesnej filozofii przedstawia co prawda skrzydło brytyjskich empirystów, ale Kant uważa je za wysoce niezadowalające. John Locke kwestionuje ściśle niezależne od poznania podstawy, a David Hume, który co prawda wybudził Kanta z dogmatycznej drzemki, podważa jednak kluczową dla systematycznie tworzonej wiedzy zasadę przyczynowości.

W obliczu kryzysu metafizyki Kant nie daje się jednak wciągać w dyskusje z żadną ze stron, lecz samodzielnie i niejako niezależnie przeprowadza postępo-

${ }^{11}$ O. Höffe, Kant, tłum. A. Kaniowski, Warszawa 1995, s. 18. 
wanie procesowe. Oznacza ono więc tylko poddanie bezstronnemu sprawdzeniu możliwości poznania rozumowego, które ma — z jednej strony — zabezpieczyć uprawnione roszczenia, a z drugiej — oddalić pojawiające się bezpodstawne zarzuty. Takiego sprawdzania i samousprawiedliwienia, zgodnie z etymologią zastosowanego tu terminu, nie można określać inaczej niż krytyką, od greckiego słowa krinein: „odróżniać”, „osądzać”, ,stawiać pod sąd”. Ostatecznie zatem, w rozszerzeniu o kantowską wykładnię, nie oznacza ono wyroku wobec rozumu, lecz „określenie jego źródeł, jak i jego zakresu i granic, wszystko to jednak na podstawie zasad naczelnych"12. Krytyka więc, według paradygmatu metodologicznego filozofii transcendentalnej, jest próbą odpowiedzi na zasadnicze pytanie: do czego w ogóle zdolna jest ludzka władza poznawcza? Rozum u Kanta zatem, poddając się autokrytyce, odsłania jednocześnie swą potęgę. Ale potęga ta, jeśli nie ma doprowadzić go na manowce antynomii, musi ostatecznie służyć samoograniczeniu, wyznaczeniu sobie samemu granic, których nie będzie w stanie w żaden sposób przekroczyć.

Można więc zadać takie pytanie: ,Jakie elementy kryzysu i krytyki, wskazane przez Immanuela Kanta, moga być pomocne dzisiaj w charakterystyce mądrości jako strategii poznania, a może nawet ludzkiego życia?". Wydaje mi się, iż przede wszystkim diagnozując kryzys jako przełom, którego domaga się oświeceniowa filozofia pierwsza, Kant przedstawia - co niezwykle istotne - pomysł przeniesienia nierozwiązywalnych problemów metafizyki na poziom jej metaanalizy; zabieg bardzo podobny do tego, jaki w wypadku analizy prawdy podejmie znacznie później Alfred Tarski.

Kantowskie definicje mądrości, jak pisze Odo Marquard,

przedstawiają zdumiewający obraz. U wczesnego krytycznego Kanta definicje filozofii są skrajnie konwencjonalne. Tam, gdzie stają się niekonwencjonalne — u późniejszego krytycznego Kanta — słowo „mądrość" nabiera w nich większej wagi ${ }^{13}$.

Dla potwierdzenia swoich tez niemiecki filozof posługuje się przytoczeniami dzieł królewieckiego filozofa z okresu późnego (po 1796 roku) oraz pierwszego zbioru pośmiertnego, tak zwanego Opus posthumum:

„Filozofia - pisze tam Immanuel Kant — jest [...] aktem poznania, którego rezultat aspiruje nie tylko do bycia nauką [...], lecz również [...] mądrością”; ,,jako droga do mądrości”, także filozofia — jako krytyka — jest „teorią wiedzy” i „badaniem mądrości”"14.

Stąd istota filozofii kulminuje „miłością rozumnej istoty skierowaną ku najwyższym celom ludzkiego rozumu"15. Inwariancje tych ostatnich słów Kant zawarł już wcześniej, pisząc:

Ponieważ bowiem mądrość rozpatrywana pod względem teoretycznym oznacza poznawanie najwyższego dobra, a pod praktycznym stosowność woli do najwyższego dobra, to nie można najwyższej samodzielnej mądrości przypisywać celu, który opierałby się jedyne na dobrotliwości ${ }^{16}$.

\footnotetext{
12 I. Kant, Krytyka czystego rozumu, Warszawa 1986, s. AXII.

13 O. Marquard, Trzy rozważania..., s. 47.

14 Ibidem.

15 Ibidem.

${ }^{16}$ I. Kant, Krytyka praktycznego rozumu, s. 210-211.
} 
Ze wspólnej wiązki połączeń i relacji filozofii i mądrości, przedstawionej przez Kanta, szczególnie dobitne są następujące słowa przytaczane przez autora „każda filozofia jest 1) autognozą, 2) autonomią nauki i mądrości, ponieważ: filozofia (doctrina sapientiae) jest sztuką tego, co człowiek powinien sam z siebie uczynić (sapere aude)"17. Istotne jest tutaj, niejako podwójne, odwoływanie się do siebie samego: autognoza i uczynić sam z siebie, jak i nazwanie filozofią nauką mądrości, tak tłumacząc wieloznaczny termin doctrina.

Autognoza, którą autor Krytyki czystego rozumu poleca tutaj jako rozwijanie mądrości, nawiązuje oczywiście do oświeceniowej kategorii Bildung, rozumianej jako samokształcenie, kształtowanie siebie przez jednostkę poprzez wymóg stałego przechodzenia od niewiedzy do wiedzy, od ignorancji do oświecenia, nieustannego doskonalenia się. W późniejszym przejęciu czy zreinterpretowaniu tego pojęcia przez niemiecki romantyzm oznacza ono wewnętrzne stwarzanie siebie samego, wypracowywanie w sobie pożądanych cech charakterologicznych, jak również gruntowne przeobrażenie podmiotu, przemianę egzystencjalną, przemianę wewnętrzną czy duchową, wedle której człowiek żyje po to, by się uformować czy formować, a ów proces formowania nie ma końca. Bildung nie tylko reprezentuje uniwersalnie ważne, zasadnicze, nowoczesne konstruowanie progresywnego kształcenia, lecz - jak pisze Michał Paweł Markowski - „to kształtowanie, czy kształcenie, konstruowanie obrazu (Bild) samego siebie nie dokonuje się przez wiedzę, lecz przez wrażliwość: otwarcie na to, co obce (wraże), i na to, co może wrazić się intensywnie w naszą wyobraźnię, nasze uczucia, nasze słowa"18.

Warto przypomnieć i podkreślić, iż wcześniej kwestię Bildung twórczo komentował Friedrich Nietzsche. Jego zdaniem dominacja modelu kształcenia, oparta przede wszystkim na kartezjańskim ideale rozwijania w wiedzy, głównie z zakresu pojęć wyraźnych, prowadzi do wewnętrznego upośledzenia, do kryzysu podmiotu. Polega on na tym, że podmiot, rozwijając w sobie tylko tę jedną kompetencję kompilowania i gromadzenia pojęć - traci naturalną spójność, ginie pod naporem pojęć roszczących sobie prawo do prawd i nie potrafi wysłowić prawdy o sobie, kryjaccej wieloraką naturę o wielorakich potrzebach. Nietzsche proponuje zatem, by podmiot, prócz gromadzenia rejestru pojęć wyraźnych, a więc wiedzy w postaci zwykłej akumulacji, kształtował w sobie też wyraźne uczucia. Iskra podjęta z kantowskiego rozumienia Bildung przez Nietzschego w pracy Richard Wagner $w$ Bayeruth ${ }^{19}$ brzmi nam niezwykle aktualnie, dowartościowując nie tylko rozwijanie kompetencji pojęciowych, tak ważnych dla społeczeństwa opartego na wiedzy, lecz także tego, co do tej pory było nieobecne, a co dziś nazywamy inteligencją emocjonalną. Filozof mówi dobitnie, że

uczucia powinny dać się kształtować, powinny być formowane przez wykształcenie. Tym samym nie przeciwstawia sobie uczuć i wrażeń pojęciom, czy też wrażliwości teorii. Nie jest zwolennikiem czystych

17 O. Marquard, Trzy rozważania..., s. 47.

18 M.P. Markowski, Polityka wrażliwości. Wprowadzenie do humanistyki, Kraków 2013, s. 220-221. Intuicja Markowskiego idzie raczej poza Kanta, sytuuje się bliżej sugestii Nietzschego.

${ }^{19}$ F. Nietzsche, Richard Wagner w Bayeruth, [w:] idem, Niewczesne rozważania, tłum. M. Łukasiewicz, Kraków 1966, s. 278. 
uczuć, lecz uczuć wyraźnych, a to oznacza poddanych refleksji. Uczucia daje się kształtować i właśnie na tym — na formowaniu wrażliwości powinno polegać wykształcenie ${ }^{20}$,

a tym samym i wzrastanie w mądrości.

Sapiencjotwórcza, jeśli tak można powiedzieć, kategoria Bildung wydaje się mieć w dzisiejszym świecie szczególnie duże znaczenie. Współczesny człowiek skazany na s cy fry z ow a ną, ograniczoną pracę, wykonuje ją w zdecydowanie innym środowisku i kulturze etycznej niż do tej pory, dysponujac także nieustannie modyfikowanymi, coraz bardziej ergonomicznymi narzędziami operacyjnymi. Z tego téz powodu szkolnictwo jako instytucja, szczególnie jako instytucja państwa, w której wykuwa się osobniczą mądrość, będzie musiała przejść, kierując się tak pojmowaną kategorią Bildung, całkowitą reorientację systemu edukacji. W czasach gdy wykonanie powtarzalnej i wyjaławiającej wewnętrznie pracy przejmują od człowieka maszyny i inteligentne narzędzia, dzieci przygotowywane są do pracy jako działalności wspólnototwórczej. W dzisiejszym świecie, w którym wiedza nie jest już dobrem ekskluzywnym, podstawowa strategia każdej edukacji powinna ogniskować się nie na zdobywaniu łatwo przecież dostępnej wiedzy, lecz głównie na kształtowaniu charakteru młodego człowieka, o czym mówił między innymi właśnie Immanuel Kant.

Dewiza sapere aude pierwszy raz pojawiła się u Horacego, jednak to Kant utrwalił ją jako hasło reprezentatywne dla epoki oświecenia. Formuła ta, jak pisze Marquard,

jest formułą definicyjną filozofii za pośrednictwem sapientia, w której amor sapientia staje się jednak audacia sapientiae. W kantowskiej definicji oświecenia uwieczniona jest definicja filozofii odnosząca się do mądrości, jednakże już nie jako u mi łow a n i a mądrości, lecz jako o d wa ga mądrości ${ }^{21}$.

W tej sytuacji pojawia się zasadnicze pytanie: „Czy jest to tylko zwyczajne przesunięcie akcentów w relacji filozofia-mądrość, czy jednak redefinicja tego, co źródłowe?". Jeśli nawet filozofia nie zatraciła jednak swojego pierwotnego celu miłowania mądrości, to — jak podkreśla autor tego komentarza — już od nowożytności, a najjaskrawiej w modernizmie, rozumienie mądrości uległo zmianie. Taka zmiana rozumienia filozofii wynika z kompilacji bardzo wielu zmiennych i tym sposobem nie można zredukować ich do jednej przyczyny. Co prawda mądrość rozumiana jako wiedza o tym, jak odróżnić to, co ważne, od tego, co błahe, by wieść prawe, owocne życie, jest nadal niewątpliwie atrakcyjna, lecz w obliczu przemian kulturowych i cywilizacyjnych, które zaszły w ostatnich dziesiątkach lat, zmienia się tė̇ to, co ważne.

Według Marka Siemka od zarania dziejów

filozoficzność definiowano mianowicie - albo wprost, albo milcząco, ale zawsze przyjmując tę definicję — jako tę sferę myślenia, refleksji, badań i dociekań, która trochę po platońsku zajmuje się tym, co jest, a nie tym, co się dzieje, staje się, powstaje i przemija. Filozofia nie zajmuje się tym zamiennym światem zjawisk, empiryczna ułudą, tą sferą gołej faktyczności i przypadkowej faktyczności22.

\footnotetext{
${ }^{20}$ M.P. Markowski, Polityka wrażliwości..., s. 178.

21 Ibidem, s. 48.

${ }^{22}$ M.J. Siemek, Wyktad z klasycznej filozofii niemieckiej, Warszawa 2011, s. 377.
} 
Zatem wiedza przez człowieka pożądana, wiedza filozoficzna, w końcu ukonstytuowała się w niezmienną wiedzę o niezmiennym absolucie, w wiedzę sub specie aeternitatis lub wprost $\mathrm{w}$ wiedzę o Bogu. Tymczasem proklamowanie wyznaczenia ścisłych granic co do ludzkiej wiedzy spowodowało specyficzne zawężenie poszukiwań filozoficznych do tego, co zmienne, przygodne, kontyngentne, arcyludzkie, jak powiedziałby Friedrich Nietzsche. Dlatego autentyczną mądrość przypisujemy jedynie temu człowiekowi, który zna swoje granice, granice własnej wiedzy i granice własnej niewiedzy, a w tej odsłonie miłowanie mądrości, po marquardowsku, pozwala człowiekowi być na tyle ludzkim, na ile się tylko da. Oczywiście wyłania się w tym momencie kolejny obszar pytań: „Co znaczy bycie ludzkim?”. Tym bardziej w obliczu tego, „na ile się da”. Problem ten podejmę w dalszej części rozważań.

Zdaniem Marquarda chrześcijaństwo przez wieki swojego trwania, czy może raczej dominowania, narzucało kulturze zachodniej perspektywę własnej wykładni tego, co rozumie jako prawdziwą mądrość. Podyktowane literą lektury tekstu biblijnego podkreślało przepaść między człowiekiem, będącym stworzeniem, a Stwórcą - Bogiem, co skutkowało tym, że ,światową" mądrość uznało za głupotę, co zdaniem autora, a contrario, prowadzi do owocnego wniosku, by dążyć do mądrości również przez rozpoznanie głupoty, która jako tło zawsze jej towarzyszy. „Dlatego dzisiaj - inaczej niż u zarania filozofii — umiłowanie mądrości nie spełnia się już w ubóstwieniu, lecz w uczłowieczeniu wiedzy"23. To już nie pełnia wszelkiej wiedzy definiuje dziś mądrość, lecz jej uczłowieczenie, czyli mądrość człowieczeństwa, zasilana dopływami myśli sceptycznej i humanistycznej.

Współczesnymi miłośnikami mądrości nie są więc akurat ci, którzy wiedzą w sposób absolutny, jak należy dobrze żyć, ani ci, którzy chcieliby udzielać wskazówek dotyczących szczęśliwego życia, lecz przeciwnie, ci, którzy liczą się z granicami ludzkiej mądrości życiowej, którzy zatem dostrzegają również głupotę ludzkiej mądrości i właśnie dlatego poszukują i akceptują to, co ludzkie, i to, co ludzkie, łącząc z tym, co arcyludzkie ${ }^{24}$.

Pojęcie ,arcyludzkie”, którym tak chętnie posługuje się tutaj Odo Marquard, nasuwa oczywiście myśl o intelektualnym pokrewieństwie z filozoficzną myślą Friedricha Nietzschego i jego podstawowymi pojęciami etyki, takimi jak wolność woli, odpowiedzialność, wina, kara czy sumienie.

Podejmując się analizy sensu tych ,arcyludzkich” pojęć (nieobecnych poza obszarem antropologicznym), Immanuel Kant chciał uświadomić ówczesnej publiczności czytelniczej funkcje i znaczenie etyki normatywnej oraz poddać krytyce moralność jako dziedzinę ludzkiego życia. Takie skojarzenie jest słuszne o tyle, o ile uściśla związek między mądrością a filozofią i wyłania z niej szczególną subdyscyplinę kompetencyjną, jaką jest etyka, chlubiąca się swoim praktycznym wymiarem. I tutaj pojawia się dalsze ważne i ciekawe pytanie. Jeżeli mądrość jest stanem pożądanym, to powinna skutkować poczuciem i doświadczaniem szczęścia, wobec czego należy zapytać: „Dlaczego temat »szczęścia« — przynajmniej jako temat naczelny został usunięty z głównego nurtu filozofii? Moja teza jest następująca: nowoczesna filozofia porzuciła temat »szczęścia«, aby pozbyć się tematu

\footnotetext{
23 O. Marquard, Trzy rozważania..., s. 48.

${ }^{24}$ Ibidem, s. 49.
} 
»nieszczęścia «"25. Bo nie mówiąc o szczęściu, nie podejmuje się jednocześnie tak często obecnego czy doświadczanego w życiu nieszczęścia. Nie stało się to jednak w sposób przypadkowy, niezamierzony i mimowolny.

Zagadnienie, czy może lepiej — problem szczęścia, został usunięty z literatury filozoficznej, a przez to też stał się bardziej widoczny w literaturze pięknej, psychoanalizie i dyskursie popularnym właśnie za sprawą Kanta. Do czasu jego dominacji na arenie filozoficznej wiedza miała wyraźny związek ze szczęściem, filozofia zaś jako umiłowanie mądrości czyniła je wiodącą kwestią etyki jako swojej subdyscypliny. Tymczasem u Kanta dokonała się swoista rewolta — królewiecki geniusz nie tylko dokonał skutecznej krytyki eudajmonizmu, lecz przy okazji wypchnął z centralnej pozycji pojęcie szczęścia, lokując na jego miejsce zagadnienie obowiązku. Marquard proponuje więc

kantowską krytykę eudajmonizmu, jego formalizm i faworyzowanie neutralnej względem szczęścia i nieszczęścia moralnej postawy obowiązku interpretować jako cenę, którą musiał zapłacić Kant na polu etyki, aby uniknąć i tak już problematycznego problemu nieszczęścia ${ }^{26}$.

W tym aspekcie można byłoby zauważyć, iż kantowski z a bi e g dotyczy zarówno szczęścia pojmowanego jako grecka eudajmonia, jak również jako greckie makarios, zazwyczaj pojmowane jako szczęście dostępne bogom, ale też użyte w greckim tekście nowotestamentowych ośmiu błogosławieństwach, gdzie powinniśmy mówić „,szczęśliwi są ci, którzy...” niż „,błogosławieni”.

Jeśli przyjrzymy się teraz szerszym skutkom idiomu filozoficznego, jaki wprowadził królewiecki filozof, całego złożonego formatu i stylu myślenia, zauważamy, że we współczesnej etyce argumentacja radzi sobie bez pojęcia szczęścia w każdym możliwym znaczeniu, także tym wskazanym powyżej. Nie jest ono już dyskutowaną kwestią. Tymczasem

trzeba zapewne — jeśli filozofia, a zwłaszcza etyka, ma być dzisiaj umiłowaniem mądrości — sprowadzić kwestię ,szczęścia” z powrotem do filozofii, jednak można to zrobić tylko wówczas, gdy przywrócimy również temat „nieszczęścia”, nie tylko jako pytanie o praktyczne sposoby unikana nieszczęścia, ale także jako pytanie: jak żyć w nieszczęściu, jeśli nie można go uniknąć? Tu konieczne będą sojusze filozofii np. z religią ${ }^{27}$.

Być może owocnym ubogaceniem takiego rozumowania byłoby skorzystanie z namysłu moralistyki sceptycznej i uzupełnienie etyki sztuką życia — ars vivendi. Piękna etymologia pojęcia savoir vivre wyłania je właśnie jako emblematyczne dla tego nurtu: savoir — „uczyć się” wywodzi się od sapere — „mądry”, do którego słowotwórczo należy również sapientia, czyli „mądrość”. Czyli: mądrze się uczyć życia.

Z przeprowadzonych tutaj rozważań można wyciągnąć wniosek, że teza, która teraz wymaga finalnie argumentacji, jest następująca: nie jest możliwe w żadnym wypadku zastąpienie życia filozofią. Ze względu na pluralizm życiowych orientacji stłoczenie go w jednowymiarowym ujęciu jest niemożliwe.

\footnotetext{
25 Ibidem, s. 50.

26 Ibidem, s. 51.

27 Ibidem, s. 51-52.
} 
Ludzie przyjmują - powiadam — wiele postaw wobec rzeczywistości: są istotami biologicznymi, dręczonymi ,głodem i miłością": są praktycznymi umysłami i dysponują technicznymi możliwościami; żyją zgodnie z prawem, mają sumienie i zdolność do refleksji: jako członkowie wspólnoty żyją w rodzinie, mają zawody, a jako istoty społeczne żyją w systemie potrzeb; są zwierzętami politycznymi, są obywatelami państwa; wikłają się w wiele różnych historii, z których jedną jest również historia powszechna; kochają sztukę, mają religię lub coś zamiast niej, mają naukę, jak również — nieświadomie lub świadomie, a wtedy jako amatorzy lub zawodowcy — filozofię ${ }^{28}$.

Redukowanie tej mnogości postaw wobec rzeczywistości do jednej jedynej postawy, nawet niezwykle istotnej, nie tyle prowadzi do życia jednowymiarowego, ile przede wszystkim do utraty poczucia rzeczywistości. Każdy człowiek jest tym bardziej wolny, im w większej liczbie światów uczestniczy, potwierdzając to swoimi wyborami i własną aktywnością. Chroniąc się przed jednowładztwem którejś z postaw praktycznych, chroni sam siebie przed byciem jednowymiarowym. Jak podpowiada Marquard:

dlatego - powtarzam to - nie jest dobrze, gdy przez akt monopolizacji uznajemy tylko jedną z postaw wobec rzeczywistości za właściwą: uznajemy jej jednowładztwo. I to właśnie filozofia staje się głupotą, gdy zamienia się w dziedzinę, która z powodu pewnego rodzaju filozoficznego fundamentalizmu chciałaby stać się tą jednowładczą postawą wobec rzeczywistości, która eliminuje i zastępuje inne postawy. Mówiąc inaczej i krócej: filozofia jako umiłowanie mądrości staje się niemądra z powodu sola philosophia ${ }^{29}$.

Filozofia nie jest, i nie może być, amuletem, który chroni swoich wiernych adeptów przed codziennym popełnianiem głupoty. Prawdziwym umiłowaniem mądrości mogą poszczycić się, zdaniem Marquarda i Kanta, tylko ci spośród filozofów, którzy, korzystając z własnej mądrości, wspierają ją na władzy sądzenia czy rozsądzania: phronesis, prudetntia.

$\mathrm{Na}$ koniec warto w tym momencie, raz jeszcze, powrócić do impulsu pochodzącego od Kanta. W swej Krytyce praktycznego rozumu pisze on między innymi:

Słowem wiedza (poszukiwana krytycznie i przygotowana metodycznie) jest wąską furtką, która wiedzie do mądrości, jeśli przez to rozumie się nie jedynie to, co powinno się czynić, ale [także] to, co powinno nauczycielom służyć za wytyczną, by dobrze i wyraźnie torować drogę do mądrości, którą każdy iść powinien, i by zabezpieczać innych przed manowcami; jest to wiedza, której strażniczką zawsze pozostawać musi filozofia; w jej subtelnych dociekaniach publiczność nie ma uczestniczyć, ale przecież [ma] korzystać z jej nauk, które dopiero po takim opracowaniu mogą stać się dla niej jasne i zrozumiałe ${ }^{30}$.

W XX wieku (ale również dzisiaj) takie faworyzowanie stanowiska filozoficznego nie spotyka się jednak z aplauzem, szczególnie wśród niemieckojęzycznych badaczy. Warto wspomnieć Helmutha Plessnera, jednego ze współtwórców współczesnej antropologii filozoficznej. W swojej książce Spóźniony naród - o politycznym uwiedzeniu ducha burżuazyjnego ${ }^{31}$ pisze on o opieszałej liberalizacji, która skutkowała tym, że rzeczywistość ekonomiczna i społeczna ewoluowała w Niemczech na tyle wolno na tle innych krajów, że poszukiwano wolności przede wszystkim w kultu-

28 Ibidem, s. 53.

29 Ibidem, s. 54 .

${ }^{30}$ I. Kant, Krytyka praktycznego rozumu, s. 78

${ }^{31}$ H. Plessner, Die verspätete Nation - Über die politische Verführbarkeit bürgerlichen Geistes, Frankfurt am Main 1998. 
rze duchowo-umysłowej. Gdy uznano, że religia jako „kluczowa wielkość” zawodzi, oczekiwania intelektualne skierowały się w stronę kultury ducha, a zatem i w stronę filozofii. Dlatego w Niemczech w czasie rozkwitu niemieckiego idealizmu zaczęto coraz częściej obserwować odgrywanie przez filozofię roli doskonałej i ekskluzywnej postawy wobec rzeczywistości. Nadmierne przeciążenie społeczno-intelektualnymi oczekiwaniami doprowadziło do tego, że bezgraniczna nadzieja w niej pokładana wkrótce zmieniała się w bezgraniczne rozczarowanie. Jeżeli więc w filozofii upatruje się jedyne wiodące narzędzie poprawy świata i jedyną najlepszą postawę wobec rzeczywistości, to wypacza się jej potencjał i nią samą. Nie ma dobrej autokracji filozofii. Najlepszą ochroną przed monopolizacją filozofii jest całkowita liberalizacja pluralizmu rzeczywistości i ludzkich postaw wobec niej.

Współcześnie musimy sobie zdać sprawę, że szukając uniwersalnego wymiaru dla pism wielkich klasyków, takich jak Immanuel Kant i jego uczniowie, ale nie tylko dla nich, szukając śladów, jakie zostawiają, szukając mądrości i pytając, czego nas mogą nauczyć starzy mistrzowie, robimy to w zdecydowanie innych warunkach poznawczych i kulturowych, niż czynili to oni sami, w zdecydowanie innym społecznym i obyczajowym kontekście: w rzeczywistości cyfrowej, która bezsprzecznie determinuje sposób jej przeżywania.

Bo z czego wykwitają najbardziej nawet abstrakcyjne i wysublimowane filozofie? Ze sposobu przeżywania rzeczywistości przez filozofujących. A co determinuje ten sposób przeżywania? Świat, w którym oni żyją. Ich codzienność. Zasób dostępnych doświadczeń. Pod względem różnorodności, bogactwa treści i gęstości dostarczanych informacji codzienność współczesnego „człowieka refleksji” jest zdominowana przez media ${ }^{32}$.

Do nich to należy mocny, ostatni ton, jaki wybrzmi w naszej świadomości.

\section{Bibliografia}

Arystoteles, Etyka Nikomachejska, tłum. D. Gromska, Warszawa 1956.

Arystoteles, Zachęta do filozofii, tłum. K. Leśniak, [w:] idem, Dzieła wszystkie, t. 6, Warszawa 2001.

Dukaj J., Po piśmie, Kraków 2019.

Gadacz T., Uniwersalne prawdy i prawa życia dla madrych ludzi na trudne czasy, Kraków 2018.

Höffe O., Kant, tłum. A. Kaniowski, Warszawa 1995.

Kant I., Co to jest Oświecenie, [w:] Z. Kuderowicz, Kant, Warszawa 2000.

Kant I., Krytyka czystego rozumu, t. 1, tłum. R. Ingarden, Warszawa 1986.

Kant I., Krytyka praktycznego rozumu, tłum. J. Gałecki, Warszawa 1984.

Markowski M.P., Polityka wrażliwości. Wprowadzenie do humanistyki, Kraków 2013.

Marquard O., Drei Betrachtungen zum Thema Philosophie und Weisheit, [w:] idem,

Individuum und Gewaltenteilung, Stuttgart 2004 [przekład polski Trzy rozważania o filozofii i madrości, tłum. P. Głowacki, J. Nowak, R. Specht, „Studia z Historii Filozofii" 2 [7] (2016), s. 45-57].

${ }^{32}$ J. Dukaj, Po piśmie, Kraków 2019, s. 337. 
Nietzsche F., Richard Wagner w Bayeruth, [w:] idem, Niewczesne rozważania, tłum. M. Łukasiewicz, Kraków 1966.

Otto R., Świętość. Elementy irracjonalne w pojęciu bóstwa i ich stosunek do elementów racjonalnych, tłum. B. Kupis, Warszawa 1999.

Plessner H., Die verspätete Nation - Über die politische Verführbarkeit bürgerlichen Geistes, Frankfurt am Main 1998.

Siemek M.J., Wykład z klasycznej filozofii niemieckiej, Warszawa 2011. 